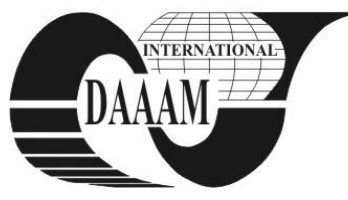

Annals of DAAAM for 2011 \& Proceedings of the 22nd International DAAAM Symposium, Volume 22, No. 1, ISSN 1726-9679 ISBN 978-3-901509-83-4, Editor B. Katalinic, Published by DAAAM International, Vienna, Austria, EU, 2011 Make Harmony between Technology and Nature, and Your Mind will Fly Free as a Bird Annals \& Proceedings of DAAAM International 2011

\title{
IMPACT OF OXYGEN CONCENTRATION ON IGNITION TIME OF BIRCHWOOD
}

\author{
MARTINKA, J[ozef]; CHREBET, T[omas] \& BALOG, K[arol]
}

\begin{abstract}
The presented paper deals with the assessment of combined impact of temperature, oxygen concentration in oxidising atmosphere and heat flux on the ignition time of birchwood. The ignition time was determined in a specially adapted hot air furnace according to ISO 871:2006 at temperatures (450 and 600$){ }^{\circ} \mathrm{C}$, density of heat flux (12.4 and 26.4) $\mathrm{kW} / \mathrm{m}^{2}$ and oxygen concentration in oxidising atmosphere (9,15 and 21) \% vol
\end{abstract}

Key words: heat flux, thermal decomposition, oxygen concentration, fire investigation, integral model of ignition

\section{INTRODUCTION}

Initiation is the most important phase of fire development (Babrauskas, 2003). This statement is supported by the fact that if initiation does not occur, fire does not start up.

Practically, a specific part of materials in fire department is in the initiation phase during the whole pre-flashover phase. Therefore, determination and comparison of the substantial initiation parameters (ignition and flash ignition temperature, ignition and flash ignition induction period and critical heat flux) enables us to make a relative comparison of materials or products from the point of fire dynamics.

Induction period of ignition or flash ignition is defined as the time interval between the thermal loading of the sample at a constant temperature or by the selected temperature programme and ignition or flash ignition.

Several authors have dealt with the assessment of the influence of individual described parameters on induction period. For example, Zachar (2010) and Terenova (2010) determined the ignition temperatures and corresponding induction periods for natural and synthetic polymers, respectively. The ignition temperatures of Beech, Oak and Poplar were $410{ }^{\circ} \mathrm{C}, 420{ }^{\circ} \mathrm{C}$ and $390{ }^{\circ} \mathrm{C}$, respectively. The corresponding induction periods were $540 \mathrm{~s}, 455 \mathrm{~s}$ and $548 \mathrm{~s}$, respectively. The ignition temperature of polymeric roof damp proof foil was $380{ }^{\circ} \mathrm{C}$ and the corresponding induction period was $7 \mathrm{~min}$. Osvaldova et al. (2006) analysed the influence of the heat flux on the induction period of ignition of selected wooden materials, while Kaciková (2007) and Kacikova and Kacik (2009) examined the influence of heat flux on the change of selected parameters of materials. Bubenikova and Velkova (2007) examined influence of temperatures on degradation of wooden materials by analysis of selected thermal degradation products (formaldehyde, acrolein and vanillin). Terziqi et al. (2010) investigated the influence of various factors on ignite combustion time. Sabau et al. (2009) investigated the influence of various factors on effectiveness of diesel engines. Zachar (2009) investigated the influence of wood distance from radiant heater on it's induction period. The results are described on Fig. 1.

During fire in the pre-flashover phase, combustible materials and products in fire department are under the simultaneous effect of increased temperature of ambient gasses (air and fire effluent), heat flux from the flame and bordering constructions, reduced oxygen concentration in oxidising atmosphere, as well as the movement of oxidising atmosphere. Hence, the goal of the presented paper is to assess the simultaneous influence of temperature, density of heat flux and oxygen concentration in oxidising atmosphere on the induction period of the ignition of birchwood as the wide-spread natural polymer.

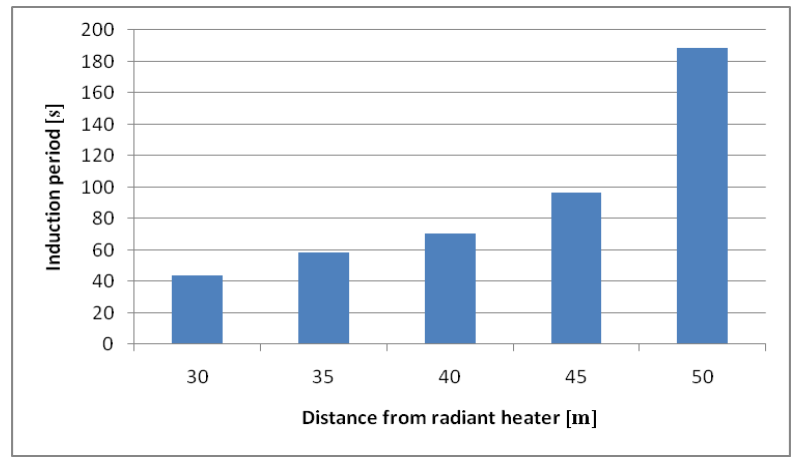

Fig. 1 Influence of Beech wood induction period on radiant heater distance (Zachar, 2009)

\section{EXPERIMENTAL DESCRIPTION}

The simultaneous influence of heat flux, temperature and oxygen concentration on induction period of ignition was assessed using the specially adapted hot air furnace according to ISO 871:2006 (Setchkin furnace). In the experiment, we used birchwood with density $540 \mathrm{~kg} / \mathrm{m}^{3}$, in the form of prism. The absolute humidity of birchwood was $8 \%$. The weight of samples was $(3 \pm 0.05) \mathrm{g}$.

Induction periods of ignition were assessed at two temperatures (450 and 600) ${ }^{\circ} \mathrm{C}$ and corresponding heat fluxes (12.4 and 26.4) $\mathrm{kW} / \mathrm{m}^{2}$ and three concentrations of oxygen $(9$, 15 and 21) $\%$ vol.

Heat flux was calculated from the known surface temperature of ceramic cylinder in the interior of the furnace (surface temperature of ceramic cylinder corresponds to the temperature of oxidising atmosphere) according to StephanBoltzmann law.

The used experimental devices are described in detail by Martinka (2009).

\section{RESULTS AND DISCUSSION}

The dependency of the induction period of birchwood ignition on temperature and oxygen concentration is shown in Fig. 2 The density of heat flux on the sample at temperatures 
$450{ }^{\circ} \mathrm{C}$ and $600{ }^{\circ} \mathrm{C}$ was $12.4 \mathrm{~kW} / \mathrm{m}^{2}$ and $26.4 \mathrm{~kW} / \mathrm{m}^{2}$, respectively.

From the experimental data, the exponential relationship of the induction period of ignition to oxygen concentration was derived. Equations (1) and (2) describe the relationship of the induction period of ignition to oxygen concentration at temperatures $450{ }^{\circ} \mathrm{C}$ and $600{ }^{\circ} \mathrm{C}$, respectively.

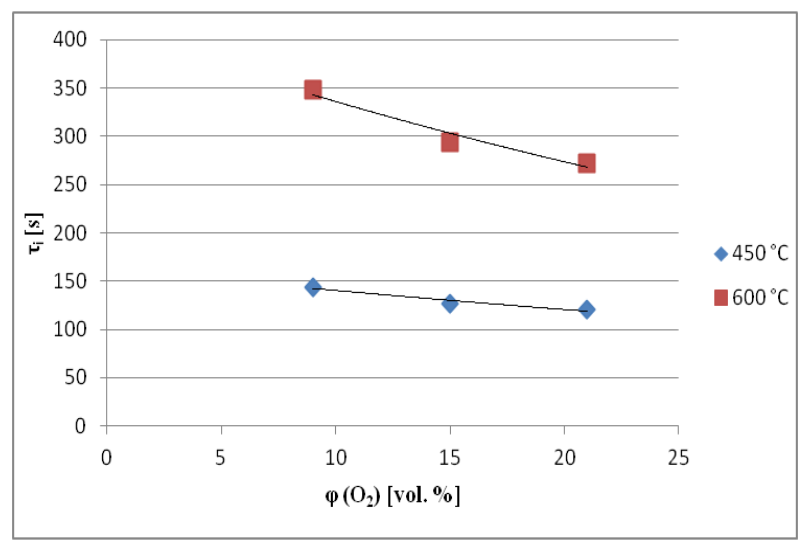

Fig. 2. Influence of temperature and oxygen concentration on induction period of birchwood ignition at the flow rate of oxidising mixture $61 / \mathrm{min}$

Close exponential relationship of induction period of ignition to oxygen concentration is confirmed by the values of coefficients of determination $R^{2}$, which approach 1 (0.96 for both equation 1 and equation 2).

$$
\begin{aligned}
\tau_{i} & =412.35 \cdot e^{-0.021 \varphi\left(\mathrm{O}_{2}\right)} \\
\tau_{i} & =163.21 \cdot e^{-0.015 \varphi\left(\mathrm{O}_{2}\right)}
\end{aligned}
$$

$\tau_{\mathrm{i}}$ - induction period of ignition [s]

$\varphi\left(\mathrm{O}_{2}\right)$ - oxygen concentration [vol. \%]

Validity of the equations (1-2) is limited particularly at low oxygen concentrations (approximately below $6 \%$ vol.), when the initiation, or the maintenance of flame burning is not possible even at extreme temperatures and heat fluxes.

Considering the arrangement of the experimental device, this can be justified by a lower heat removal from the burning zone. At the flow of oxidising mixture equal to $6 \mathrm{l} / \mathrm{min}$ and temperature of $600{ }^{\circ} \mathrm{C}$, oxygen concentration had only a negligible impact on the induction period of ignition in the analysed period. At temperature $600{ }^{\circ} \mathrm{C}$, time increase of the induction period would become more distinct only at oxygen concentrations below $9 \%$ vol.

Luo et al. (2009) carried out similar experiments. Cited author investigated the influence of oxygen concentration from (20 to 100$) \%$ vol. on ignition temperature and its induction period. The results indicating that the oxygen concentration has a significant influence on ignition temperature.

\section{CONCLUSION}

From the presented results we can state that the induction period of ignition (and hence the ignition temperature) depends apart from the temperature and oxygen concentration in oxidising atmosphere. In addition, heat flux has a significant influence on the induction period. However, the quantification of the heat flux influence was with the applied experimental device not possible. Further research has to be oriented at the development of the device that will allow independent setting of temperature of oxidising mixture and heat flux on the sample.

\section{ACKNOWLEDGEMENTS}

This article was written based on the financial support of VEGA Grant Agency under contract No. 1/0436/09 and under contract No. 1/0471/10.

\section{REFERENCES}

Babrauskas, V. (2003). Ignition Handbook, Fire Science Publishers, ISBN: 0-9728111-3-3, Issaquah

Bubenikova, T. \& Velkova, V. (2007). Prchavé produkty termickej degradácie dreva. Delta : vedecko-odborný časopis, Vol. 1., No. 2., 2007, pp. 18-20, ISSN 1336-3824

Kacikova, D. (2007). Zmeny vybraných charakteristík smrekového a smrekovcovho dreva po zatažení sávalým tepelným tokom. Acta Facultatis Xylologiae, Vol. 49., No. 1., 2007, pp. 53-59, ISSN 1336-3824

Kacikova, D. \& Kacik, F. (2009). Vplyv termického pôsobenia na zmeny lignínu smrekového dreva. Acta Facultatis Xylologiae, Vol. 51., No. 2., 2009, pp. 71-78, ISSN 13363824

Martinka, J. (2009). Možnosti skúmania vplyvu koncentrácie kyslíka na produkty horenia a termického rozkladu syntetických polymérnych materiálov. Delta : vedeckoodborný časopis, Vol. 3, No. 6., 2009, pp. 34-37, ISSN 1337-0863

Osvaldova, L. et al. (2006). Odolnost' jednotlivých častí smerkového dreva voči zapáleniu, Proceedings of Technologické spracovanie dreva, International Scientific Conference, 2006, Zvolen, ISBN 80-228-1666-3, pp. 143148, Technical University in Zvolen, Zvolen

Sabau, A. et al.. (2009). Computer Code for Combustion Modelling in Diesel Engines, Annals of DAAAM for 2009 \& Proceedings of the 20th International DAAAM Symposium, 25-28th November 2009, Vienna, Austria, ISSN 1726-9679, ISBN 978-3-901509-70-4, Katalinic, B. (Ed.), pp. 0617-0618, Published by DAAAM International Vienna, Vienna

Terenova, L. (2010). Hydro-isolating Belts in Structural Members of New Buildings in Terms of The Fire Safety, Proceedings of Fire Engineering, $3^{\text {rd }}$ International Scientific Conference, 2010, Zvolen, ISBN 978-80-8924138-5, Mračková, E.: Marková, I. (Ed.), pp. 403-410, Technical University in Zvolen, Zvolen

Terziqi, A. K. et al. (2010). Thermal Load Impact on Steam Parameters for Cooling the Shaft Furnace, Annals of $D A A A M$ for 2010 \& Proceedings of the 21st International DAAAM Symposium, 20-23rd October 2010, Zadar, Croatia, ISSN 1726-9679, ISBN 978-3-901509-73-5, Katalinic, B. (Ed.), pp. 0173-0174, Published by DAAAM International Vienna, Vienna

Zachar, M. (2009). Vplyv ohrevu na termickú degradáciu vybraných druhov dreva, Technická univerzita vo Zvolene, ISBN 978-80-228-2060-8, Zvolen

Zachar, M. (2010). Selected Decidious Wood Species Flash Ignition and Ignition Temperature Determination, Proceedings of Fire Engineering, $3^{\text {rd }}$ International Scientific Conference, 2010, Zvolen, ISBN 978-80-8924138-5, Mračková, E.: Marková, I. (Ed.), pp. 431-438, Technical University in Zvolen, Zvolen

Luo, S. Y. et al. (2009). Experimental study on oxygenenriched combustion of biomass micro fuel. Energy, Vol. 34, No. 11., 2009, pp. 1880-1884, ISSN 0360-5442 